\title{
AN EXPLORATORY STUDY OF LONG SUPPLY CHAIN COMPETITION: SELECTED CASES IN THE SOUTH AFRICAN AEROSPACE SECTOR
}

\author{
L.J. Richardson ${ }^{1 *}$ and D.R. Snaddon ${ }^{2}$ \\ ${ }^{1,2}$ School of Mechanical, Industrial and Aeronautical Engineering \\ University of Witwatersrand, South Africa \\ lauriejrichardson@gmail.com, roy.snaddon@wits.ac.za
}

\begin{abstract}
This article investigates how supply chains, especially long supply chains, compete in the South African aerospace industry. A multiple case study methodology is employed, involving six selected firms. Semi-structured interviews provide the primary source of data. Multiple case analysis identifies similarities in competitive dimension criteria for supplier-firm and customer-firm units in the supply chain. Results indicate that supplier-firm units compete on the basis of speed, dependability, quality, flexibility, and cost. Customer-firm units compete on the basis of speed, quality, and flexibility. The results also identify focus areas for future research into how long supply chains compete in the South African aerospace industry.
\end{abstract}

\section{OPSOMMING}

Hierdie artikel ondersoek hoe voorsieningskettings, veral uitgerekte kettings, meeding in die Suid-Afrikaanse lugvaartindustrie. ' $n$ Meervoudige gevallestudie-metodologie is gevolg waartydens ses ondernemings bestudeer is. Semi-gestruktureerde onderhoude was die primêre bron van data. Meervoudige gevalle-analise identifiseer ooreenkomste in die mededingingskriteria vir leweransiers- en kliëntefirmas. Die resultate toon dat leweransiers kompeteer op spoed, betroubaarheid, kwaliteit, aanpasbaarheid en koste. Kliëntefirmas ding mee op grond van spoed, kwaliteit en aanpasbaarheid. Die resultate identifiseer fokusareas vir verdere navorsing op hierdie terrein.

\footnotetext{
${ }^{1}$ The author was enrolled for an MSc Eng (Industrial) degree in the School of Mechanical, Industrial and Aeronautical Engineering, University of Witwatersrand.

*Corresponding author.
} 


\section{INTRODUCTION}

The global aerospace market is increasingly influenced by offset and technology transfer issues, with Original Equipment Manufacturer's OEMs looking to low-cost places like China to exploit these opportunities [1]. South Africa is positioned in this global aerospace market for the manufacture of OEM aerospace components. While the South African industry provides cost-effective services on an international scale, they are becoming very expensive compared with India, China, and the Eastern bloc [2]. With aerospace component manufacture outsourced to South Africa from northern hemisphere countries, shipping costs are high and delivery times are long. These cost and time barriers involved in importing material and exporting finished products erode South Africa's competitive advantage in global aerospace markets. Previous research into South African composite manufacturer practices [3], which included aerospace firms, identified supply chain management as an area needing further research to improve competitiveness.

The objective of this article is to find what contributes to the competitiveness of supply chains in the South African aerospace industry. A multiple case study methodology is employed. With case study research being exploratory in nature, no initial hypotheses or propositions are examined [4]. The research is guided by problem statements. The main problem statement to be researched is: "How do long supply chains compete?"

Competitive dimensions are critical success factors that impact on profit for competitive firms [5]. Competitive dimensions include speed, dependability, quality, and flexibility. Assessing how a firm performs on competitive dimensions can help to determine how to manage aspects of the supply chain [6]. This leads to the research sub-problems that contribute to the main research problem:

- Sub-problem 1: "How do long supply chains compete on speed?"

- Sub-problem 2: "How do long supply chains compete on dependability?"

- Sub-problem 3: "How do long supply chains compete on quality?"

- Sub-problem 4: "How do long supply chains compete on flexibility?"

The remainder of this paper is arranged as follows: Section 2 provides a review of supply chain and competitive dimension literature. Section 3 describes the research methodology. Section 4 covers multiple case analysis. Section 5 presents important multiple case results. A summary and discussion is found in section 6, further work in section 7, and references in section 8 .

\section{LITERATURE REVIEW}

\subsection{Supply chain and long supply chain}

Stevens [7] defines a supply chain as a system whose constituent parts include material suppliers, production facilities, distribution services, and customers linked together via the flow of materials and information. Jain \& Benyoucef [8] describe long supply chains in the global competition market as "very complex, with many parallel physical, information and financial flows occurring in order to ensure that products and/or services are delivered in the right quantities, with the requested quality to the right place in a cost effective manner at the right time". The long supply chain follows the supply chain process outlined by Stevens [7], but with some distinguishing attributes and operational uncertainties as a result of globalisation [8]:

- The short supply chain has traditionally focused on efficiency, which may not be viable due to transportation distances and costs involved in longer supply chains.

- Large geographical distances involved in long supply chains lead to a lack of visibility and control procedures.

- Shorter product life cycles and the volatility of demand increase the risk of product obsolescence within a supply chain. 
The term long supply chain in this research will refer to supply chains where members who trade goods and services are geographically distant from one another, generally on different continents. The management of flow through the long supply chain is examined using competitive dimensions.

\subsection{Competitive dimensions}

Hayes \& Wheelwright [9] identify competitive strategy as that which a firm pursues to compete in the marketplace. Manufacturing strategy needs to support this overall competitive strategy [10]. According to Harland et al. [6], manufacturing strategy can also be applied to a supply network strategy, where competitive dimensions extend to the end customer and each supply network actor. Gunasekaran and McGaughey [11] explain that competitive dimensions of cost, speed, dependability, quality and flexibility are the primary basis for competition and the foundation for creating, combating, and sustaining competitive advantage. These competitive dimensions are explained below:

- Hayes and Wheelwright [9] describe price, and therefore cost, as the most familiar competitive dimension, but as not the only basis on which a business can compete.

- Slack et al. [12] define speed as "how fast customers can be served", the elapsed time between a customer requesting a product or service and receiving it in full.

- Slack [10] explains dependability (sic) or reliability as keeping the delivery promises one makes to the customer.

- Slack [10] describes quality as "doing things right".

- Upton [13] defines flexibility as "the ability to change or react with little penalty in time, effort, cost or performance".

This research directly addresses the competitive dimensions of speed, dependability, quality, and flexibility. Cost is examined within these dimensions. Slack [10] explains that the competitive dimensions of speed, dependability, quality and flexibility all contribute both directly and indirectly to low-cost manufacture. Increasing speed means materials spend less time in inventory, where they would attract both direct material costs and overhead storage costs. Greater dependability results in reduced overhead costs from chasing late deliveries and rescheduling production. Higher quality reduces rework, scrap, and waste. Better flexibility, when changing from the manufacture of one product to another, results in little loss of output.

\subsubsection{Speed}

The ideas of Stalk \& Hout [14] to convert to a time-based supply chain are used for the speed competitive dimension in the framework:

- Provide each firm with better and timelier information about product orders and needs.

- $\quad$ Shorten the lead times between firms by removing the obstacles to time compression.

- Synchronise lead times and capacities among the levels or tiers of the supply chain so that more work can flow up and down the chain in a coordinated manner.

\subsubsection{Dependability}

According to Slack [10], the focus of dependability should be to meet the required delivery conditions decided by the firm from the supplier, and to the customer. Processes and procedures for planning ahead with suppliers and customers, managing internal firm and supplier capacity effectively, and coordination between firms are required in meeting delivery conditions. 


\subsubsection{Quality}

Quality is a multi-dimensional competitive dimension in that it can be interpreted in a number of different ways:

- Garvin [15] identified eight dimensions of quality: performance, features, reliability, conformance, durability, serviceability, aesthetics, and perceived quality.

- Crosby [16] defined quality as "conformance to requirements".

- Juran [17], through his quality message of "fitness for use", approached quality as having external and internal dimensions.

\section{Quality management}

The Juran trilogy of quality planning, quality control, and quality improvement outlines a quality plan that is achieved through managerial processes. Managerial processes are sequences of activities that convert goals into results [17]. This is a continuous process, where quality improvement results are fed back into the quality planning process. The Juran trilogy has also been applied to supplier relationship management [18], highlighting its applicability in a supply chain setting.

\section{Quality planning}

Godfrey [19] explains that quality planning begins with the identification of customers and their needs, to produce products that respond to those needs. A primary output of the quality planning process is a recommended sourcing strategy, which looks at the procurement methodology for both commodity and strategic items [18].

The establishment of trust between supply chain members is also fundamental to the quality planning, control, and improvement process [18]. Trust reflects the confidence of one party in a two-way relationship that the other party will not exploit its vulnerabilities (Sako [20], from Ghosh \& Fedorowicz [21]).

\section{Quality control}

Quality control is the activity of evaluating actual performance, comparing actual performance with the customer's needs, and taking action on the difference [18]. The means of measuring quality needs to be established, where the critical performance metrics and processes for capturing this information are determined. The critical performance metrics and processes can be established in a performance measurement system.

\section{Quality Improvement}

According to Juran [17], quality improvement is "the activity of raising quality performance to unprecedented levels". Dyer \& Nobeoka's research [22] into the Toyota supply chain found that, as an OEM, Toyota facilitates continuous improvement with its suppliers to reduce waste and improve its competitive position. This is primarily achieved through the use of the kyoryoku kai, or supplier association.

\subsubsection{Flexibility}

Flexibility is often viewed as an adaptive response to environmental uncertainty [23, 24], and is required for a firm to respond quickly and efficiently to a dynamic market [25]. Slack [10] takes a systems perspective on flexibility dimensions, and includes product, mix, volume, and delivery flexibility. From the literature, flexibility focuses on manufacturing flexibility $[13,24]$ and supply chain flexibility $[25,26]$. 


\section{METHODOLOGY}

\subsection{Framework for research}

The framework uses the competitive dimensions of speed, dependability, quality, and flexibility to provide qualitative measurements to classify the research data. An 'other' category is also included to catch any other factors that cannot be classified in the listed competitive dimensions. This is done for both the direct supplier-firm and the direct customer-firm relationship. This is in the next figure.

Competitive dimensions for customer-firm and supplier-firm units of analysis

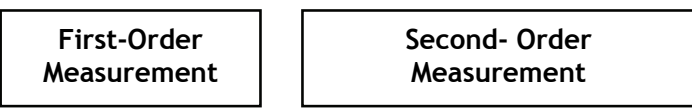

1. Better and timelier information

2. Lead time compression

3. Synchronisation

1. Processes and procedures to ensure denendabilitv

1. Meaning of quality

2. Quality planning

3. Quality control

4. Quality improvement

1. Meaning of flexibility

2. Achievement of flexibility

Flexibility

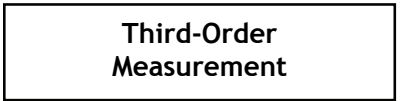

1. Communication

2. IT

1. Material order volume and frequency

2. Capacity constraints

Other

1. Ways to improve competitiveness

\section{Quality planning process \\ 2. Trust}

1. Quality control process

2. Performance measurement

\section{(1)}
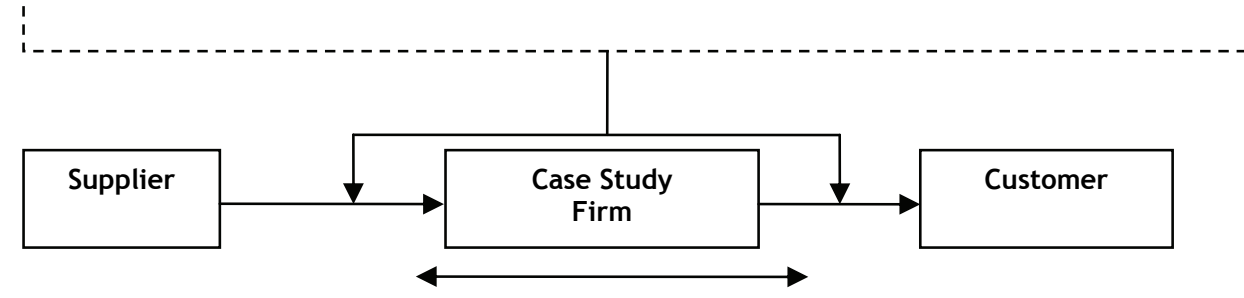

Material flows

Information flows

Figure 1: Framework for research 


\subsection{Research description}

Little literature examines long supply chains and supply chains in the South African context. Case study research is used as it is exploratory in nature and attempts to determine 'how' or 'why' events occur [4] (Yin, 2003, p. 6). This uses multiple case studies that examine several related situations, where links between the situations may highlight similar aspects. As the goal of this research is to determine how to make long supply chains more competitive, the use of several South African aerospace firms provides a better idea of operating practices than a single firm. This study researches six firms.

\subsubsection{Data collection}

The primary source of evidence is obtained from face-to-face semi-structured interviews. These are done with personnel involved on a strategic business level in procurement and supply chain activities.

\subsubsection{Data analysis}

Initially, individual case studies use the logical approach of McCutcheon \& Merideth [27] to analysing data, where logical connections among the events are sought, relying on prior knowledge obtained from the literature survey. Multiple case studies use the outcomes from each case to draw cross-case conclusions. Tables described by Miles \& Huberman [28] are used for qualitative data analysis. These tables are presented in this paper.

\section{MULTIPLE CASE ANALYSIS}

Multiple case analysis presents tabular results and discusses important results where relevant.

\subsection{Firm size}

Firm size is classified according to number of employees in each firm in Table 1. Firm sizes in this study vary.

\begin{tabular}{|l|c|c|c|c|}
\hline Firm & $\begin{array}{c}\text { Less than } \\
50 \text { people }\end{array}$ & $\begin{array}{c}50 \text { to } 100 \\
\text { People }\end{array}$ & $\begin{array}{c}100 \text { to } 500 \\
\text { People }\end{array}$ & $\begin{array}{c}500 \text { to } 1000 \\
\text { people }\end{array}$ \\
\hline Firm A & & & & $X$ \\
\hline Firm B & & $X$ & & \\
\hline Firm C & $X$ & & & \\
\hline Firm D & & & & $X$ \\
\hline Firm E & $X$ & & & \\
\hline Firm F & & & & $X$ \\
\hline
\end{tabular}

\subsection{Firm classification}

Table 1: Classification of firm size

Case study firms are classified as either manufacturing or service firms. Four of the six firms in this study are manufacturing firms; the remaining two are service firms. 


\subsection{Supplier classification}

Fourteen out of $16(88 \%)$ are manufacturing-based suppliers. The remaining two are servicebased suppliers.

Twelve out of 16 suppliers (75\%) have long supply chains; two (12.5\%) have short supply chains, as they are located within South Africa. The remaining two (12.5\%) may have either long or short supply chains.

The strategic importance of suppliers in terms of their competitive dimensions is classified as follows:

- Seven are strategically important from a dependability competitive dimension perspective;

- Six are strategically important from a distinct cost competitive dimension perspective;

- One supplier is strategically important from a quality competitive dimension perspective;

- One supplier is strategically important from a speed competitive dimension perspective;

- One supplier is strategically important from a flexibility competitive dimension perspective.

The two South African suppliers, both services, compete on dependability and cost respectively.

\subsection{Customer classification}

Eight out of 12 customers are manufacturing based-customers; the remaining four are service-based customers.

Nine customers have long supply chains as they are located within South Africa; two may have either long or short supply chains; the remaining customer is unclassified.

The strategic importance of customers in terms of the competitive dimensions is classified as follows:

- Ten customers are strategically important from a cost competitive dimension perspective;

- Two customers are strategically important from a quality competitive dimension perspective;

The one South African customer, a service, competes on cost.

\section{MULTIPLE CASE RESULTS}

\subsection{Supplier firm results}

Overall findings are presented in Table 2 on how to compete for the supplier-firm unit of analysis.

\subsection{Customer firm results}

Overall findings are presented in Table 3 on how to compete for the customer-firm unit of analysis. 


\begin{tabular}{|c|c|}
\hline Dimensions & How to compete \\
\hline Speed & $\begin{array}{l}\text { - } \quad \text { Share information between firm and supplier } \\
\text { - } \quad \text { Use customised or advanced IT solutions between firm and } \\
\text { supplier, but also acknowledge the softer issues } \\
\text { - Inventory, transhipment mode (air versus freight) and } \\
\text { improved planning for lead time reduction }\end{array}$ \\
\hline Dependability & $\begin{array}{ll}\text { - } & \text { Automated processes and procedures } \\
\text { - } & \text { Performance monitoring and feedback between firm and } \\
& \text { suppliers } \\
\text { - } \quad \text { Understand supplier requirements }\end{array}$ \\
\hline Quality & $\begin{array}{l}\text { - } \quad \text { Compete on internal and external dimensions of quality; } \\
\text { conformance to requirements through documentation } \\
\text { - } \quad \text { Quality planning begins with customers and their needs } \\
\text { - } \quad \text { Tmicable supplier-firm relationships } \\
\text { - } \quad \text { but trust also requires documentary proof } \\
\text { Various incoming quality control procedures in place; } \\
\text { product traceability through documentation important } \\
\text { - Performance measures in place } \\
\text { Quality improvements through feedback, reports, } \\
\text { infrequent audits }\end{array}$ \\
\hline Flexibility & $\begin{array}{l}\text { - Delivery, volume, and mix flexibility important } \\
\text { - Flexibility achieved through communication, relationships } \\
\text { and cost factors }\end{array}$ \\
\hline Other & - Compete through cost factors \\
\hline
\end{tabular}

Table 2: Results for how to compete for the supplier-firm unit of analysis

\begin{tabular}{|l|c|}
\hline Dimensions & How to compete \\
\hline Speed & $\begin{array}{l}\text { - Share information between firm and customer } \\
\text { - Use customised or advanced IT solutions between firm and } \\
\text { customer, but also acknowledge the softer issues } \\
\end{array}$ \\
- Inventory, transhipment mode (air versus freight) and IT \\
for lead time reduction
\end{tabular}

Table 3: Results for how to compete for the customer-firm unit of analysis

While the supplier-firm and customer-firm units of analysis are analysed separately in this research, some important similarities and differences between units can be identified:

- On the speed competitive dimension, the supplier-firm unit cites improved planning for lead time reduction. This is not mentioned as a result for the customer-firm unit. This 
may be because planning with suppliers is often dependent on the customer placing an order with the firm, which cannot always be planned for in advance.

- For the dependability competitive dimension, no similarities were found in the results for the customer-firm unit, whereas similarities were found for the supplier-firm unit. This may be because reliable on-time delivery of goods to the customer is dependent on internal firm operations (e.g. manufacturing time). The interviewees picked for this research may have had more insight into external firm operations than into internal firm operations because of their job focus on the supply chain, so no similarities were found.

- For quality, the supplier-firm unit interprets quality from an internal and external dimension, whereas the customer-firm unit interprets quality only from an external dimension. A possible reason for the external dimension for both the supplier-firm and the customer-firm unit is that customer requirements depend on both supplier and customer input. The internal dimension result may only exist for the supplier-firm unit because it is the focal case study firm requiring technical specifications such as quality documentation from its suppliers. This is different from the focal case study firm requiring technical specifications such as quality documentation from its customers, which does not seem logical. This is a directional issue between supplier, firm, and customer.

- Flexibility results between supplier-firm and customer-firm units vary. For the supplier-firm unit, delivery, volume, and mix flexibility are important, but only delivery flexibility is important for the customer-firm unit. The author of this paper is unable to suggest a possible reason for this result. Communication and relationships are given as important to achieving flexibility in the supplier-firm unit, but not in the customer-firm unit. This may be a result of the interviewees chosen for this research having more insight into the supplier-firm unit of the supply chain.

- For the other result, cost factors are given as important for the supplier-firm unit but not for the customer-firm unit. This may be because costs are relatively fixed for the customer-firm unit, but could vary for the supplier-firm unit. Large customers may dictate pricing to the firm, who has little choice but to settle for the given price to survive. But negotiation and bargaining over cost may occur with smaller suppliers, who have little choice but to take the price set for them by the firm to survive.

\section{SUMMARY AND DISCUSSION}

This research process has identified the South African aerospace industry as small and heterogeneous. It has also proved difficult to include only global suppliers and customers for this study. As a result, a small number of South African suppliers and customers were used. To complicate matters further, South African suppliers are on an indirect long supply chain, in that they are based locally but receive materials from overseas suppliers for the locally-based firms. Results should therefore not be generalised. This is due to the small sample size and the difficulty of fulfilling long supply chain criteria for all cases.

It was found that results for the supplier-firm and the customer-firm are often similar in nature. This may be due to the supplier-firm and the customer-firm units of analysis being discussed directly after one another in the same interview. Another possibility is that supplier, firm, and customer operations are strongly linked together; one cannot completely separate them for individual analysis.

This research identifies suppliers as strategically important to the firm from a dependability and cost perspective; and customers as strategically important from a cost perspective. These results explain how long supply chain relationships in the South African aerospace industry compete. 
From similarities in the multiple case analysis, supplier-firm units compete on aspects of speed, dependability, quality, flexibility, and cost. Customer-firm units compete on aspects of speed, quality, and flexibility. While cost is examined within the competitive dimensions of speed, dependability, quality, and flexibility in this research framework, it also appears as an individual 'other' competitive dimension. This may be because the link between contributions of speed, dependability, quality, and flexibility to cost, as described by Slack (1991), is not necessarily explicit in nature. Supplier cost, or price of goods, may be individually evaluated by the firm in the same way that a required quality level or lead time, for example, is evaluated when obtaining goods. So while speed, dependability, quality, and flexibility all contribute to the overall dimension of cost, some of these competitive dimensions may be also be individually evaluated alongside cost when it comes to judging supplier performance.

\section{FURTHER WORK}

This research has been exploratory. It identifies focus areas for future research into how long supply chains compete in the South African aerospace industry. Further work includes:

- Speed: Supplier-firm and customer-firm units of analysis have some form of customised or advanced IT in place. Further research should investigate the role of IT, as well as its associated 'softer' issues, in improving long supply chain competitiveness.

- Dependability: The investigation of processes and procedures to ensure dependability in this research has been broadly addressed. This may be why no similarities were found for the customer-firm unit of analysis. Further research should focus on other dependability literature for analysis. This could look specifically at the strategic importance of suppliers to South African aerospace firms from the dependability competitive dimension.

- Quality: Documentation and traceability appear to be necessary in planning and controlling for quality in the aerospace supply chain. Further research should investigate processes and procedures that are in place for traceability and management of quality documentation between supplier, firm, and customer.

Further investigation into the role of performance measures in the aerospace supply chain should be undertaken. This would look at the role of performance measures and systems, as well as the competitive performance measures with which the aerospace supply chain aligns itself.

- Flexibility: While results for flexibility have been found for the supplier-firm and customer-firm units of analysis, the author believes that time spent on research into the semantics of flexibility could be better spent on the speed, dependability, and quality competitive dimensions.

- Other: Results broadly point to cost as an important factor in improving competitiveness in the supplier-firm relationship. Future research may investigate the role that cost plays in the long supply chain in the South African aerospace industry. The link between the contributions of speed, dependability, quality, and flexibility to cost within the long supply chain, as described by Slack [10], may also be determined.

\section{ACKNOWLEDGEMENTS}

With thanks to the National Aerospace Centre at the University of Witwatersrand for funding this research. 


\section{REFERENCES}

[1] Bales, R.R., Maull, R.S. \& Radnor, Z. 2004. The development of supply chain management within the aerospace manufacturing sector. Supply Chain Management: An International Journal, Volume 9, Number 3, pp. 250-255.

[2] Haupt, P. 2005. Assegai: A strategy for a sustainable, economical and growing aerospace industry. www.amts.co.za/assegai.pdf, last accessed June 17, 2008.

[3] Snaddon, D.R. \& Reid, R. 2007. Diagnosis of selected composite manufacturers using 'In-site': An evaluation. Unpublished.

[4] Yin, R.K. 2003. Case study research: Design and methods, $3^{\text {rd }}$ ed. Sage Publications.

[5] Snaddon, D.R. 1996. The manufacturing mix, Technovation, Vol. 16 No 8, pp. 385-396.

[6] Harland, C.M., Lamming, R.C. \& Cousins, P.D. 1999. Developing the concept of supply strategy, International Journal of Operations and Production Management, Vol 19 No.7, pp. 650-673.

[7] Stevens, J. 1989. Integrating the supply chain, International Journal of Physical Distribution and Materials Management, Vol. 19, No. 8, pp. 3-8.

[8] Jain, V. \& Benyoucef, L. 2008. Managing long supply chain networks: Some emerging issues and challenges. Journal of Manufacturing Technology Management, Vol. 19 No. 4, pp. 469-496.

[9] Hayes, R.H. \& Wheelwright, S.C. 1984. Restoring our competitive edge: Competing through manufacturing, John Wiley and Sons, New York.

[10] Slack, N. 1991. The manufacturing advantage, Mercury, Chatham.

[11] Gunasekaran, A. \& Mcgaughey, R. 2002. Information technology/ information systems in $21^{\text {st }}$ century manufacturing. International Journal of Production Economics, 75, pp. 1-6.

[12] Slack, N., Chambers, S. \& Johnston, R. 2007. Operations management, $5^{\text {th }}$ ed, Prentice Hall.

[13] Upton, D.M. 1994. The management of manufacturing flexibility. California Management Review, Winter, 36, 2, pp. $72-89$.

[14] Stalk, G. Jr. \& Hout, T.M. 1990. Competing against time - how time based competition is reshaping global markets, The Free Press, New York, NY.

[15] Garvin, D.A. 1988. Managing quality. New York, Free Press.

[16] Crosby, P.B. 1996. Quality is still free, McGraw-Hill.

[17] Juran, J.M. \& Godfrey, A.B. 1999. How to think about quality. Juran's quality handbook, $5^{\text {th }}$ ed., McGraw-Hill.

[18] Donovan, J.A. \& Maresca, F.P. 1999. Supplier relations. Juran's quality handbook, $5^{\text {th }}$ ed., McGraw-Hill.

[19] Godfrey, A.B. 1999. Total quality management. Juran's quality handbook, $5^{\text {th }}$ ed., McGraw-Hill, pp. 14.1-14.35.

[20] Sako, M. 1991. The role of trust in Japanese buyer-supplier relationships, Ricerche Economiche, Vol. 45, pp. 449-474.

[21] Ghosh, A. \& Fedorowicz, J. 2008. The role of trust in supply chain governance. Business Process Management Journal, Vol. 14, No. 4 pp. 453-470.

[22] Dyer, J.H. \& Nobeoka, K. 2000. Creating and managing a high performance knowledge-sharing network: The Toyota case. Strategic Management Journal, 21, pp. 345-36.

[23] Gupta, Y.P. \& Goyal, S. 1989. Flexibility of manufacturing systems: Concepts and measurements. European Journal of Operational Research, 43, pp. 119-135.

[24] Gerwin, D. 1993. Manufacturing flexibility: A strategic perspective. Management Science, Vol. 39, No. 4, pp. 395-410.

[25] Vickery, S., Calantone R. \& Droge C. 1999. Supply chain flexibility: An empirical study. Journal of Supply Chain Management, Summer, 35, 3 pp. 16-24.

[26] Duclos, L.K., Vokurka, R.J. \& Lummus, R.R. 2003. A conceptual model of supply chain flexibility. Industrial Management and Data Systems, 103/6, pp. 446-456.

[27] McCutcheon, D.M. \& Meredith, J.R. 1993. Conducting case study research in operations management. Journal of Operations Management, Vol. 11, pp. 239-256.

[28] Miles, M.B. \& Huberman, A.M. 1994. Qualitative data analysis: An expanded sourcebook. $2^{\text {nd }}$ ed., Sage, Thousand Oaks, California. 
